\title{
Perceptions of Parents Regarding the Influencing Cognitive Function of Stunted Children: A Qualitative Study in Jatinangor District, West Java, Indonesia
}

\author{
Meita Dhamayanti ${ }^{1, *}$, Stephani Supriadi ${ }^{3}$, Anindita Noviandhari ${ }^{3}$, Raden Tina Dewi Judistiani ${ }^{2}$ \\ ${ }^{1}$ Departement of Child Health, Hasan Sadikin General Hospital -Faculty of Medicine Universitas Padjadjaran, Bandung, Indonesia \\ ${ }^{2}$ Departement of Public Health, Faculty of Medicine Universitas Padjadjaran, Bandung, Indonesia \\ ${ }^{3}$ Study Program of Pediatric Specialist, Hasan Sadikin General Hospital - Faculty of Medicine Universitas Padjadjaran, \\ Bandung, Indonesia \\ *Corresponding author: meita.dh@gmail.com
}

Received November 19, 2018; Revised January 04, 2019; Accepted January 17, 2019

\begin{abstract}
Indonesia is the fifth worldwide rank of nations with a high number of stunted children (30-39\%). In Jatinangor District, 55 of 144 elementary school children were stunted. Stunted is risk factor on decreasing of cognitive function. This study was conducted to investigate the factors influencing the cognitive function of 10-12 years old stunted children. Interviews were conducted on the parents of 10-12 years old stunted children with cognitive interference in Cikeruh, Jatinangor District, West Java between July to September 2018. A qualitative method by focused group discussion was done by trained personnel from the Midwifery Department and Pediatric residents. Ten of twenty parents of stunted children with cognitive interference were included in the interview consisted of seven mothers, one father, one aunt and one grandmother. The result of the discussion revealed that caused of stunted was said to be the familial factor. The parents stated that vegetables and fruits were rarely consumed and their children had poor appetites. Nutritional habits were the main factor influencing the cognitive problems of the stunted children.
\end{abstract}

Keywords: cognitive, stunted, qualitative study

Cite This Article: Meita Dhamayanti, Stephani Supriadi, Anindita Noviandhari, and Raden Tina Dewi Judistiani, "Perceptions of Parents Regarding the Influencing Cognitive Function of Stunted Children: A Qualitative Study in Jatinangor District, West Java, Indonesia." American Journal of Clinical Medicine Research, vol. 7, no. 1 (2019): 14-17. doi: 10.12691/ajcmr-7-1-3.

\section{Introduction}

According to the data from UNICEF (2011), Indonesia was the fifth country in the world with high number of stunted children aged $<5$ years after [1] India (61.7 millions), [2] Nigeria (11 millions), [3] Pakistan (9.6 millions), [4] China (8 millions), and [5] Indonesia (7.5 millions). Based on the results of a study by Riskesdas, there was an increase in the prevalence of short stature in Indonesia, 35.6\% in 2010 and $37.2 \%$ in 2013, in which $18.0 \%$ of them were classified as very short and $19.2 \%$ as short [2]. The result of the study in District Pangandaran almost 30\% Elementary School student were short stature or stunted, $20 \%$ of which had cognitive disorders [3].

The clinical manifestation of stunted children is associated with decreased cognitive and motor functions, language/linguistic, besides economically it will increase the maintenance of health expenses [4]. These are related to a high morbidity and mortality. The short stature is associated with decreased learning capacity, shortened period of education and working ability that might influence their future life productivity and lower income. Therefore, short stature might become a predictor of poor quality of the human resources that might decrease the productivity of a nation [4]. A woman who was stunted during her childhood period, tend to have a stunted child that make inter-generation cycles of poverty and decreased the quality of human resource that is not easy to overcome [5]. Insufficient nutritional intake and poor health condition might impair the child's growth and development [6].

Cikeruh village in Jatinangor District was chosen as the study location, is a semiurban district very close to Bandung city as capital of West Java Province. The potential nature's resources in Cikeruh village are forestry.

This study was a part of a community service to find out the contributing factors of the stunting children in West Java.

\section{Method}

The qualitative study was conducted between July to September 2018 at, Cibesi and Hegarmanah primary 
schools, at Cikeruh village, Jatinangor District. Cikeruh is a villaget with the areas are agriculture and Univisitas Padjadjaran campus. It is easy to reach Cikeruh village through permanent roads, about half-hour distance from Jatinangor $(5 \mathrm{Km}), 20 \mathrm{Km}$ from Bandung, the capital of West Java Province.

The subject of the community service was a 10-12 years old primary school child. An anthropometric measurement was done to find out the body heights, and cognitive evaluation using questionnaires. Short stature was defined based on the WHO criteria $Z$ score HAZ $\leq-2$. A cognitive level was examined using Mini-Mental Scale Examination (MMSE) consisted of 30 questions divided into 7 dimensions with the results; $24-30$ was classified as normal, 18-23 mild, and 0-1 severe cognitive impairment.

This study to find out the condition or phenomenal status within a certain condition. During this phase of the study, focus group discussion (FGD) was conducted by direct interview with the parents of stunted and abnormal cognitive children.

The parents were selected by purposive sampling to fulfill the needed total to be matched with the data from the elementary school and saturated data from the field.

The Ethical Committee of Health Research, Medical Faculty of Universitas Padjadjaran, had approved this study.

\section{Results and Discussion}

A total of 144 students were included in the study, 55 (38.19\%) of which were stunted (Table 1). Based on Riskesdas 2013, this was a high prevalence compared to the national prevalence $35.1 \%$.
Table 1. Demographic distribution of short statured children and cognitive status

\begin{tabular}{|l|c|c|c|}
\hline Characteristic & $\begin{array}{c}\text { Stunted } \\
\text { N (\%) }\end{array}$ & $\begin{array}{c}\text { Normal } \\
\text { N (\%) }\end{array}$ & Total \\
\hline Age (year) & & & \\
10 & $17(38)$ & $49(50)$ & $66(46)$ \\
11 & $13(29)$ & $31(31)$ & $44(31)$ \\
12 & $15(23)$ & $19(19)$ & $34(24)$ \\
\hline Sex & & & \\
Male & $23(51)$ & $53(54)$ & $76(53)$ \\
Female & $22(49)$ & $46(46)$ & $68(47)$ \\
\hline Grade & & & \\
4 & $12(27)$ & $16(16)$ & $28(19)$ \\
5 & $14(31)$ & $41(41)$ & $55(38)$ \\
6 & $19(42)$ & $42(42)$ & $61(42)$ \\
\hline Cognitive Status & & & \\
Normal & 25 & 79 & 104 \\
Mild & 19 & 15 & 34 \\
Severe & 1 & 5 & 6 \\
\hline
\end{tabular}

Based on the MMSE scoring, most of the school children $(104=72.22 \%)$ had normal cognitive status while 24 (53.33\%) of children with short stature had sub-normal cognitive status.

Bhoomika et al revealed that compared to non-stunted children, the stunted children had neuropsychologic interference and different cognitive function, attention, memorizing process, visual perception and verbal comprehension [7]. The low psychologic performance indicates severe interference of attention, executive function, visuospatial, comprehensive and memory.

The result of the group discussion with 10 parents of stunted children was shown in Table 2.

Table 2. The results of discussion / interview

\begin{tabular}{|c|c|c|c|}
\hline Topic & \multicolumn{3}{|l|}{ Parent's Answers } \\
\hline \multirow{11}{*}{ Child’s characteristics } & \multirow{4}{*}{ Child order in the family } & First child & 2 \\
\hline & & Second child & 1 \\
\hline & & Third child & 3 \\
\hline & & Fourth child & 2 \\
\hline & \multirow{2}{*}{ Birth Weight } & $>2,5$ kilogram & 1 \\
\hline & & $\leq 2,5$ kilogram & 7 \\
\hline & \multirow{3}{*}{ Comparison with peers of the same age } & Looks smaller in weight & 8 \\
\hline & & Looks shorter in height & 12 \\
\hline & & Normal & 1 \\
\hline & \multicolumn{2}{|l|}{ Looks smaller than peers since $<2$ years old } & 3 \\
\hline & \multicolumn{2}{|l|}{ History of stunted in the family } & 7 \\
\hline \multirow[t]{5}{*}{ Factors related with Health facility } & Intergrated Health Care & Weight is measured monthly at the Posyandu & 8 \\
\hline & & Height was never measured before the study & 2 \\
\hline & Immunization & Completed basic immunization & 5 \\
\hline & & Completed follow-up immunization at School & 2 \\
\hline & & $\begin{array}{l}\text { Healthcare providers had to actively come in order to } \\
\text { give immunization }\end{array}$ & 3 \\
\hline \multirow[t]{10}{*}{ Dietary Factors } & \multicolumn{2}{|l|}{ Unscheduled meal habits } & 13 \\
\hline & Difficulty in eating & Reluctant to eat & 25 \\
\hline & & Forget to eat & 1 \\
\hline & & Prefer playing & 8 \\
\hline & & Must be forced to eat & 12 \\
\hline & & Willing to eat if others are eating & 3 \\
\hline & \multicolumn{2}{|l|}{ Habit of eating snacks } & 16 \\
\hline & \multicolumn{2}{|l|}{ Does not like to eat fruits and vegetables } & 2 \\
\hline & \multicolumn{2}{|l|}{ Lack of fruits and vegetables in diet } & 3 \\
\hline & \multicolumn{2}{|l|}{ Prefer to drink milk } & 4 \\
\hline \multirow[t]{2}{*}{ Disease } & \multicolumn{2}{|l|}{ History of chronic illness } & 5 \\
\hline & \multicolumn{2}{|c|}{ Prone to sickness when weather/season changes } & 2 \\
\hline
\end{tabular}


Among 10 interviewed parents, 7 were mothers, the other was a father, an aunt, and a grandmother. Most of them had more than three children. Most of the stunted children in this study were the third child. Birth weights of the school children were mostly normal (> $2.5 \mathrm{~kg})$, only one had body weight $2.5 \mathrm{~kg}$.

Most of the parents complained about the lower body weights and heights of their children (compared with the same age children). Several of them realized that this problem was identified when their child was examined at the Posyandu and some considered this stunted condition as a genetic chain in the family.

In relation to the health service in the community, these parents informed that they routinely brought their under-five children to the Posyandu for health check and vaccination. About the eating pattern, most of the children had irregular eating/dining time which as only once or twice in a day. Some of the children began to have an eating problem at age 6 months, the others started the eating problems appeared since the beginning of school time when they preferred to play more. The children did not like to take vegetables and fruits. As the results, some of the children had severe or chronic diseases at the younger age, especially during the climate changes (dry or rainy season).

A long period malnutrition might cause disorders of the growth, development and future behavior of the child. Malnourished school-age children might have lower IQ level, problems with cognitive function, school achievement and behavioral problems that might persist until their adolescent period $[8,9]$.

Low cognitive level of stunted children might cause other problems such as low self-confidence, feeling different from their other normal friends. These potentially might cause problems or difficulties when they are starting higher education or career. So they should obtain the right education in order to get good self-confidence [10].

Both long-term nutritional deficits as reflected by stunting and current micronutrient status, especially iron status, significantly affected cognitive performance [11]. Children infested by parasites, especially girls, exhibited poorer cognitive performance than those of non-infested children. Possible links between parasite infestation and cognitive outcomes are reduced school attendance due to illness, lack of concentration, or nutritionally by affecting absorption of micronutrients such as iron and iodine [11]. Children born to a parent who was stunted by age 24 months had significantly lower developmental quotients than children born to a non-stunted parent [12].

In the present study children, stunting, Selenium deficiency, and anemia were associated with poor cognitive performance. [13]. The brain is one of the organs with a high concentration of selenium, in addition in cases of Se deficiency it is the organ that remains Se replete the longest [13].

Nutritional status in the early life could have a profound effect on children's health status as well as their ability to learn, think analytically and socialize with others and their capacity to adapt to changes [14]. Initial stunting would be associated with poorer general cognitive outcomes. Consistent with this hypothesis, a child's initial height was found to be a significant predictor of non-verbal IQ.
Children with more optimal height at arrival had higher nonverbal IQ measures [15]. There was no association between stunting and social maturity, or age-appropriate daily living skills among these preschool-aged children, but a robust and significant association with a measure of cognitive and fine-motor capacities. This finding suggests that, apart from height, the impact of stunting on children's development may be relatively 'invisible' to parents who do not anticipate that their children will achieve specific intellectual milestones during the preschool years. These adverse effects can be prevented by effective early interventions that include both supplementary nutrition and compensatory developmental stimulation [16]. Undernutrition affects some areas of the brain involved in cognition, memory and locomotor skills. The brain has major energy demands in early childhood and most cerebral growth occurs in the first 2 years of life [17]. Literature suggests that cognitive functions may be adversely affected in very low birth weight or VLBW $(<1.5 \mathrm{~kg})$ and/or very preterm ( $<28$ weeks of gestation) infants. Such children had lower volumes of cerebral cortex, cerebellum, hippocampus and corpus callosum[18]. Improvements in height for age $\mathrm{Z}$ score (HAZ) over time or recovery from a stunted to a non-stunted HAZ is associated with improved cognition. [19]. In addition of cognitive function, stunted have association with emotional symptoms during middle adolescents [20].

\section{Conclusion}

Eating problem is a factor that might affect the stunted condition of children in Jatinangor. The parents' knowledge and awareness about the health service are good but still insufficient about the eating and nutritional habits. Therefore, further counseling should be conducted intensively and individually using modules, brochures or leaflets. The use of KIA should be more intensively conducted in the community.

\section{Acknowledgements}

The authors thank all the staff at the Cikeruh, and Jatinangor Primary Health Centres for their contribution to enable this study in these districts, also to field researchers, Bunga Mars, Putri Anisa, and Devi Yuli Agustini, for their faithful effort made for this study. Funding for this study came from Community Service of Internal Grant from Universitas Padjadjaran.

\section{References}

[1] Rachmi CN, Agho KE, Li M, Baur LA. Stunting, Underweight andOverweight in hildren Aged 2.0-4.9 Years in Indonesia: Prevalence Trends and Associated Risk Factors. journalpone. 2016 1-17.

[2] Riset Kesehatan Dasar 2013. Jakarta: Badan Penelitian dan Pengembangan Kementrian Kesehatan RI; 2013.

[3] Rodman T, Meita D, Eddy F, Kusnandi R. Different Result of Cognitive Impairment Screening in Adolescent Aged 10-12 Years with Normal and Short Stature in Pangandaran District . American Journal of Clinical Medicine Research, 2017, Vol. 5, No. 3, 26-30. 
[4] Prendergast A, Humphrey J. The stunting syndrome in developing countries. Paediatrics and International Child Health. 2014; 34.(4): 250-65.

[5] Martorell R, Zongrone A. Intergenerational influences on child growth and undernutrition. Paediatr Perinat Epidemiol. 2012; 26(suppl 1): 302-14.

[6] Soetjiningsih. Tumbuh kembang remaja dan permasalahannya, editor. Jakarta: Sagung Seto; 2010; 53-7.

[7] Kar BR, Rao SL, Chandramouli BA. Cognitive development in children with chronic protein energy malnutrition. Behavioral and Brain Functions 2008, 4:31. 2008; 4(31): 1-12.

[8] World Health Organization. Child growth standards and their identification od severe acute malnutrition in infants and children. A joint statement. Geneva: World Health Organization. 2009.

[9] Uauy R, Kain J, Corvalan C. How can the Developmental Origins of Health and Disease (DOHaD) hypothesis contribute to improving health in developing countries? Am J Clin Nutr. 2011; 96(6).

[10] WHO. World Health Assembly (WHA) Global Nutrition Targets 2025: Stunting Policy Brief. 2014.

[11] Perignon M, Fiorentino M, Kuong K, Burja K, Parker M, Sisokhom S, et al. Stunting, Poor Iron Status and Parasite Infection Are Significant Risk Factors for Lower Cognitive Performance in Cambodian School-Aged Children. PLoS ONE. 2014; 9 (11): 1-11.

[12] Walker SP, Chang SM, Wright A, Osmond C, Grantham SM. Early Childhood Stunting Is Associated with Lower Developmental Levels in the Subsequent Generation of Children, The Journal of Nutrition. 2015; 145 (4): 823-28.
[13] Gashu D, Stoecker BJ, Bougma K, Adish A, Haki G, Marquis GS. Stunting, selenium deficiency and anemia are associated with poor cognitive performance in preschool children from rural Ethiopia. Nutrition journal. 2016; 15 (8): 1-8.

[14] Woldehanna T, Behrman JR., Araya MW. The effect of early childhood stunting on children's cognitive achievements; Evidence from young lives Ethiopia. Ethiop J Health Dev. 2017; 3(12): 75-84.

[15] Kroupina M G, Eckerle J K, Fuglestad A J, Toemen L, Moberg S, Himes $\mathrm{J} \mathrm{H}$, et al. Associations between physical growth and general cognitive functioning in international adoptees from Eastern Europe at 30 months post-arrival. Journal of Neurodevelopmental Disorders. 2015; 7(36): 1- 9.

[16] Desmond C. Casae D. The association between stunting and psychosocial development among preschool among preschool children: a study using the South African Birth to Twenty cohort data. Child care, health and development. 2015; 40: 900-10.

[17] Prendergast, A. J. and J. H. Humphrey. The stunting syndrome in developing countries. Paediatrics and International Child Health. 2014; 34(4): 250-265.

[18] Purandare, Mitravinda S. Influence of Birth Weight and Stunting on Selected Cognitive Functions of Young Children in Low Socioeconomic Areas of Muumbai City. Journal of Psychosocial Research. 2015; 10: 295-303.

[19] Sudfeld, C. R., et al. Linear Growth and Child Development in Low- and Middle-Income Countries: A Meta-Analysis." Pediatrics. 2015; 135(5): e1266-e1275.

[20] Dhamayanti M, Deliana P, Bukkar F. Association of stature and mental problems among adolescents in Jatinangor District, West Java. Med J Indones. 2018; 27(3): 209-12.

(C) The Author(s) 2019. This article is an open access article distributed under the terms and conditions of the Creative Commons Attribution (CC BY) license (http://creativecommons.org/licenses/by/4.0/). 